Natalia Mospan

ORCID ID 0000-0001-8610-7965

Doctor of Sciences in Pedagogy, Associate Professor, Professor of English Philology and Translation Department, Borys Grinchenko Kyiv University, 13-b Tymoshenko Str., 04212 Kyiv, Ukraine, Monavik@ukr.net

Valentina Slipchuk

ORCID ID 0000-0002-9552-029X

Doctor of Sciences in Pedagogy, Associate Professor, Professor of the Department of Medical and General Chemistry, Bohomolets National Medical University, 13 Shevchenko Blvd, 01601 Kyiv, Ukraine, slipchukvl@gmail.com

\title{
INTERNATIONAL STUDENTS IN HIGHER EDUCATION MEDICAL INSTITUTIONS IN UKRAINE: CURRENT STATE OF PLAY AND PROSPECTS
}

\begin{abstract}
The present study explores current state of play of international medical student population in Ukraine. Theirnumber in national medical universities has been constantly rising since 2006. Ukraine is a country of international medical students' destination for higher medical or pharmaceutical education. Ukraine is not only one of the biggest suppliers of international students to the European Union in European Higher Education Area, but it is also a host country for international students primarily from Asia and Africa. The survey aimed at studying international medical students' current needs and perspectives was conducted at Bogomolets National Medical University in 2019. The university is chosen as it is situated in the capital city. Sample was composed of 60 first-year international medical students, chosen at a random. It allowed students to provide feedback on their country of origin, educational background, preferences, satisfaction in quality of educational service in a host country, ways of financing the study and future career plans. Among the reasons of international students' choice of Ukraine as a place for study are their preference of the country, high quality education, friends' advice and geographical location. The research results show that international medical students consider Ukraine not only as high quality medical education provider but as perspective country for postgraduate employment. The research results allow us to hypothesise that the current needs and perspectives of international medical students at one medical university are likely to be typical for other national medical universities and for Ukraine in whole. It is concluded, that increasing international students' population requires regular monitoring and special researches by universities and government. These measures will make benefits in international university strategy and national educational policy coordination.
\end{abstract}

Keywords: employment; higher medical education; international medical students; medical universities; survey of students' needs and perspectives.

https://doi.org/10.28925/1609-8595.2020.3.7

Introduction. Globalization and internationalization make a huge impact on the development of higher education in the world. The Bologna Process was started to modernise European higher education systems in accordance to these challenges. The Bologna Process aims at the harmonisation of academic standards and the mutual recognition of degrees across Europe in order to increase mobility and competitiveness. One of the results of these processes is increasing the international students' amount. They have to solve many problems in European higher education institutions: potential (fill the gap in human resource shortages), financial (an alternative source of profit in the condition of university autonomy), qualitative (provide educational service of high quality). According to the Bologna Process Implementation Report 2018, that presents the number of outward degree mobile students inside and outside the EHEA, around 810000 students from EHEA countries are studying abroad. Such big EHEA countries as Germany, France, Ukraine and Italy show the highest numbers of outgoing mobile students. For Ukraine - it is $65 \%$ (European Commission, 2018, p. 255). Among the top 8 countries that cover half of the total outward mobility flows are Germany that accounts $12.3 \%$, Ukraine $-7.7 \%$, France $-7.5 \%$ and Italy $-6.5 \%$ of the outward mobile students within the EHEA (European Commission, 2018, p. 256).

In these processes, medicine has been granted an 
exceptional status. Europe has around 440 medical schools that produce 70,000 medical graduates every year (Medical Research Education in Europe, 2012, p. 3). Medical schools in England are able to fill up to 7.5\% of their places with overseas students from outside of the European Union. These students pay the full cost of their tuition and living costs at medical school (Expansion of Undergraduate Medical Education, p.6). According to the British Medical Association (BMA) report for 20142015 «international students paid an estimated $£ 4.8$ billion in tuition fees to UK universities. This accounts for over $14 \%$ of total university income. Some $88 \%$ $£ 4.2$ billion - of this fee income was paid by students from outside the EU» (Migration Advisory Committee Call for Evidence, 2017, p. 1). «Any fall in the number of non-EU students to UK medical schools has serious consequences for medical school funding, as non-EU students pay, in England, fees of between $£ 25,000$ and $£ 35,000$ per year» (Migration Advisory Committee Call for Evidence, 2017, p. 2). However, the latest data shows that «the overall number of applicants from the EU was static (in 2018), remaining at 6,610. And for medicine, the number of EU applicants fell from 1,800 to 1,660. The fall comes despite the government's confirmation in July that EU students enrolling in English universities in the first academic year after Brexit will pay the same tuition fees as British students« (Busby, 2018). This evidence highlights the importance of international students for financial support of European HEIs.

While the international student mobility appears at a risk of decrease in the $\mathrm{EU}$, the number of foreign student population tend to be increased in other countries. As the recent researches show «the number of students from Asian and African countries to study medicine in China has been on the rise» (Li \& Sun, 2019); «over 600 international medical students commence training in Australian medical schools each year» (Breen \& Birrell, 2020). In Ukraine we can observe the situation when since the entering the Bologna process in 2005 the international students' availability has become a part of national educational policy. The data for 2017 indicates that $\ll 64,000$ foreigners attend universities in Ukraine. Despite war and economic uncertainty, international students flood into Ukraine every year. One of the appeals is a cheap education for starters. Even the typically pricey medical schools in Ukraine cost students only from $\$ 3,000$ to $\$ 5,000$ per year. In 2016, the top providers of foreign students to Ukrainian universities were Azerbaijan, Turkmenistan, India, Nigeria, Morocco, Georgia, Jordan, Iraq, China and Uzbekistan» (Romanenko, 2017).

International medical students when appear in a host country need to have adaptation to unknown cultural environment. The way in which cultural background impacts the international student's experience is an issue of current researches (Huhn, et al., 2018; HerrmannWerner, et al, 2018; Byrne, et al., 2019; Iorga, et al, 2020), as well as international medical students' attitude toward educational methods (Potočnjak, et al, 2018).
Research Focus. The study concentrates in particular on services for international medical students, because in Ukraine medicine as a field is more attractive for international students.

We would like to note, that while working at this issue we met the difference in definition of the key term - «international students» in European and Ukrainian educational discourse. Thus, in Europe the term «international students» refers to non-European students. «International students are those who have gained their previous qualification from a country outside of Europe. It is precisely these full degreeseeking students that are likely to have additional support needs compared to all other foreign students» (Kelo et al., 2010, p. 23). «'International student' means a third-country national who has been accepted by a higher education institution and is admitted to the territory of a Member State to pursue as a main activity a full-time course of study leading to a higher education qualification ...» (Attracting and retaining international students, 2018, p. 6).

In Ukraine the term «international students» refers to all foreign students, non-citizens of Ukraine (Law on Higher education of Ukraine, 2014; Sysoieva \& Mospan, 2015). Thus, the term «foreign students» is more common in national official documents in higher education field. Therefore, for the purposes of this article, international students are defined as foreign students, non-citizens of Ukraine.

Furthermore, this article focuses on several levels of analysis. First, there is an attempt to provide an overview of current state of play in national educational policy in the provision of international medical student services. The article also aims to shed light on the quantity of international medical students in Ukrainian medical HEIs. And finally, the perspectives of the international medical students are presented and analysed in an effort to make sense of their needs, satisfaction and future career plans. The research questions were: What is a current situation with international medical students in Ukraine? Why do they choose Ukraine for medical education? What are their preferences, needs or employment perspectives?

Research Methodology. The research objectives were identified through the following primary methods: 1) theoretical literature review of the existing materials available on that problem: in particular, national publications, educational reports and legislative documents; official site of Bogomolets National Medical University as a place for conducting student survey. The university is chosen as trends in increasing international students' population have been observed here for recent years; 2) a quantitative student survey was designed and conducted for data collecting for this article. A simple random technique has been used for sampling.

1) Theoretical literature review makes it possible to analyse current national educational policy and to collect data of the quantity of international medical 
students in Ukrainian medical HEIs for 2015-2016. An official site of Bogomolets National Medical University was used for examining number of international medical students for 2015-2019.

2) The 10-question online questionnaire was designed in Google Forms format and administered online for about 100 first-year international medical students (at a random) in Bogomolets National Medical University in the beginning of academic year, September - October, 2019. As one part of the first-year international students is doing the course in English and other part - in Ukrainian, the questionnaire was provided in English (it was responded by 48 students) and in Ukrainian (it was responded by 12 students). As a result, the survey is based on responses from 60 first-year international medical students in Bogomolets National Medical University in 2019. It has become a piloting survey that, on example of one university, allowed students to provide feedback on their country of origin, educational background, needs, preferences, experience, satisfaction with educational services at their host institution, ways of financing the study and their future career plans.

The collected data and questionnaire responses were analysed using predominantly quantitative methods. 1) The collected data of the quantity of international medical students in Ukrainian medical HEIs for 2015-2016 was summarised and resulted in tables and diagrams. 2) For the questionnaires responses analysis the collected data was calculated, summarised and presented in diagrams for better visual perception.

Research Results. In Ukraine nowadays, one of the problems in modernizing the higher medical education is to reach a compromise between national higher education traditions in the field of pharmaceutical education and the challenges of globalization, internationalisation and Europeanization in higher education.

Prospective directions of medical education modernization in pharmaceutical field have been caused by important changes in the state policy since 2014. These include: higher education democracy, medical university autonomy, changes in employment of graduates, classroom load reduction for teaching staff in pharmaceutical industry, providing vocational training of master of pharmacy, privileged students reduction, Ukrainian diplomas recognition in the world, increasing of satisfactory consumers of educational services in pharmaceutical industry, the national medical universities entry in the international rankings of HEIs, increasing the number of foreign students, teaching staff training on the British Council programmes to improve the quality of teaching and science, increasing publications in international science databases, launching an automated control system in national medical universities, students' practical training in university clinics (postgraduate education), providing basic international course-books in educational process (Amosova, 2017).

The increasing of foreign students' number in national medical universities is considered to be one of the prospective directions of medical education modernization in Ukraine. In 2014-2015 in Ukrainian HEIs 21389 foreign students studied from 124 countries. And their number has been constantly increasing since 2006 (See Fig.1) (Fisun, 2015).

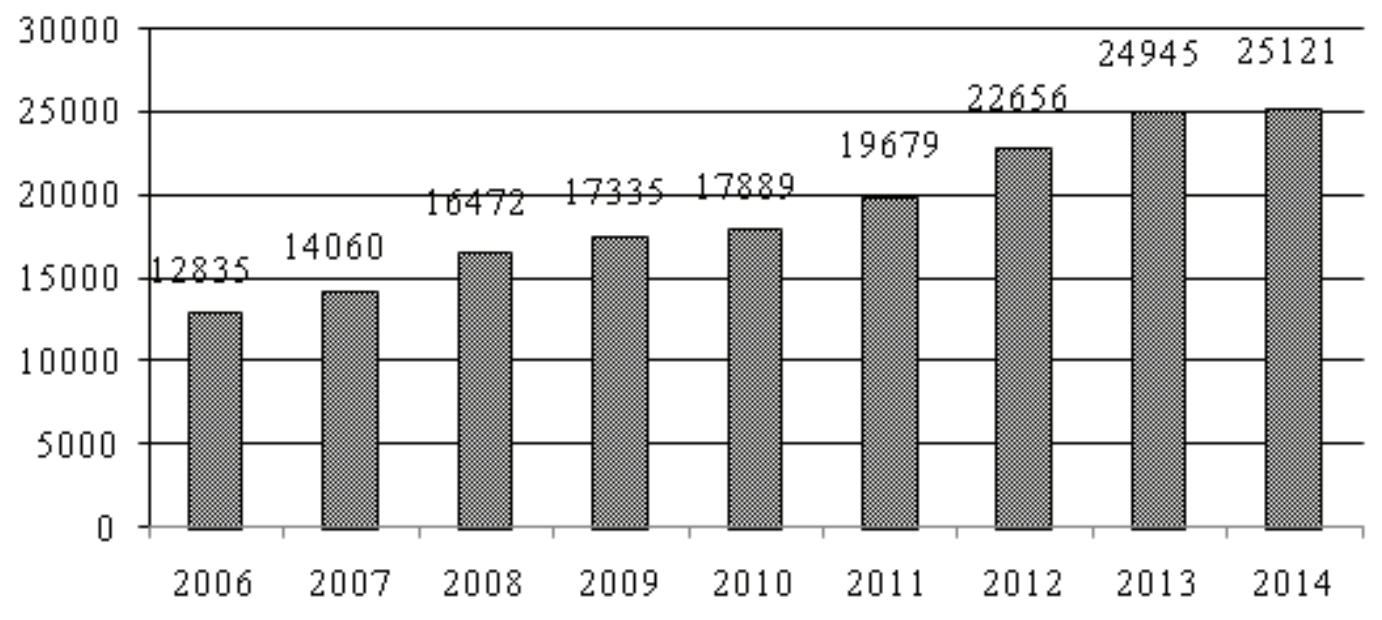

Figure 1. Dynamics of foreign students' enrolment in medical universities of Ukraine (2006-2014)

In 2014-2015 in Ukraine, 19973 foreign students obtained professional training in health care in national medical universities. Master programmes in «Pharmacy» for foreign students were provided by the following medical universities of Ukraine: National Pirogov Memorial Medical University, Vinnytsya; Donetsk National Medical University; Dnipropetrovsk State Medical Academy; Zaporizhzhya State Medical University; Ivano-Frankivsk National
Medical University; Danylo Halytsky Lviv National Medical University; Lugansk State Medical University; National University of Pharmacy; Bogomolets National Medical University; Odessa National Medical University; I. Horbachevsky Ternopil National Medical University. The largest number of foreign students obtains Master programmes in «Pharmacy» at the National University of Pharmacy (See Table 1). 
Foreign students number in medical universities in Ukraine (2014-2015)

\begin{tabular}{|c|l|c|}
\hline \multicolumn{1}{|c|}{ Medical university } & \multicolumn{1}{|c|}{ Number of foreign students } \\
\hline 1 & Kharkiv National Medical University & 3296 \\
\hline 2 & Odessa National Medical University & 1897 \\
\hline 3 & National Pirogov Memorial Medical University, Vinnytsya & 1761 \\
\hline 4 & Zaporizhzhya State Medical University & 1727 \\
\hline 5 & Ivano-Frankivsk National Medical University & 1673 \\
\hline 6 & Dnipropetrovsk State Medical Academy & 1504 \\
\hline 7 & Bogomolets National Medical University & 1179 \\
\hline 8 & National University of Pharmacy & 1046 \\
\hline 9 & I. Horbachevsky Ternopil National Medical University & 997 \\
\hline 10 & Danylo Halytsky Lviv National Medical University & 862 \\
\hline 11 & Bukovinian State Medical University & $\mathbf{1 9 9 7 3}$ \\
\hline 12 & Ukrainian State Medical Dental Academy & Total \\
\hline
\end{tabular}

In 2014-2015 professional training in health were India (3943 students), Nigeria (2193 students) care obtained foreign students from 13 countries in and Morocco (1744 students) (See Fig. 2) (Slipchuk, medical universities of Ukraine. The top 3 countries 2019).

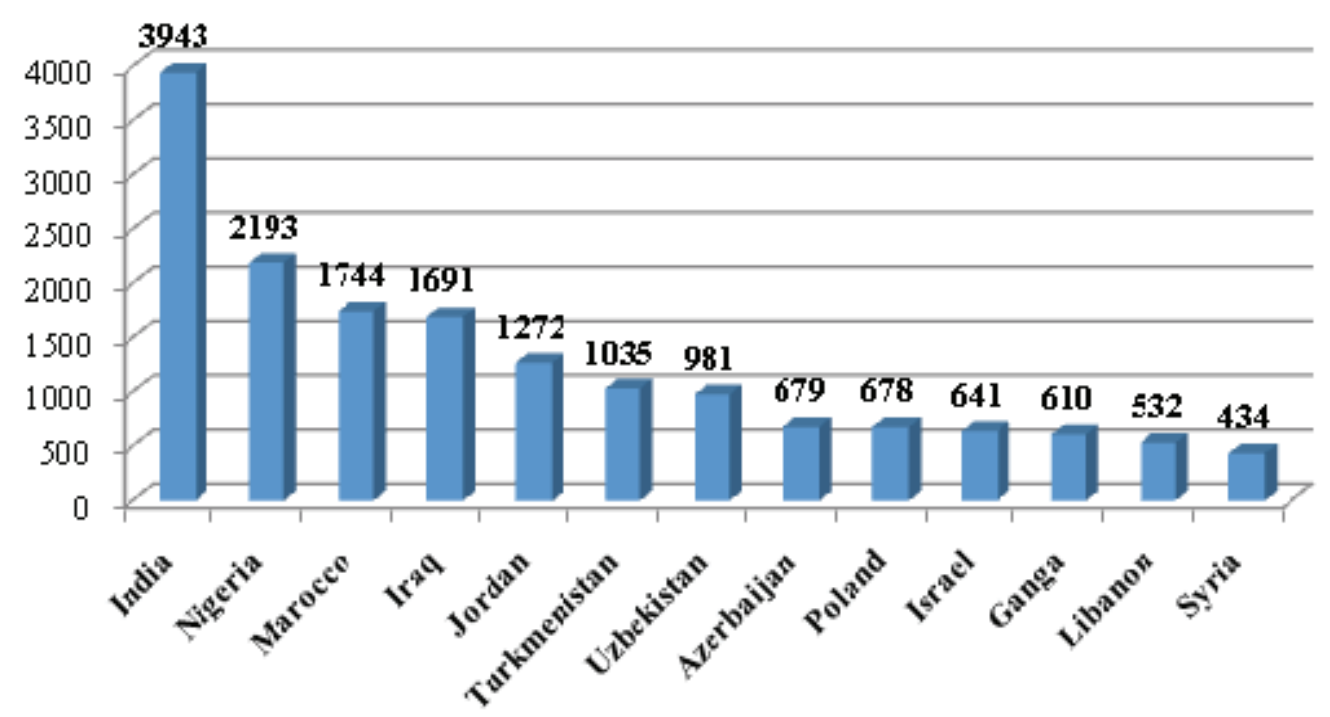

Figure 2. Foreign students' country origin in medical universities of Ukraine (2006-2014)

In Ukraine among the leaders in providing Postgraduate Education and Shupyk National Medical postgraduate education and medical internships for Academy of Postgraduate Education. foreign students are Kharkiv Medical Academy of

Table 2

Foreign postgraduates number in medical universities in Ukraine (2014-2015)

\begin{tabular}{|c|l|c|}
\hline № & \multicolumn{1}{|c|}{ Medical Universities of Postgraduate Education } & Number of foreign students \\
\hline 1 & Kharkiv Medical Academy of Postgraduate Education & 272 \\
\hline 2 & Shupyk National Medical Academy of Postgraduate Education & 227 \\
\hline 3 & Bogomolets National Medical University & 131 \\
\hline 4 & Zaporizhzhya Medical Academy of Postgraduate Education & 70 \\
\hline \multicolumn{2}{|c|}{ Total } & $\mathbf{7 0 0}$ \\
\hline
\end{tabular}


We would like to note, that since 2015 in Bogomolets National Medical University have been observed the trends in increasing the number of foreign students in Master and postgraduate programmes, taught in English. Thus, in 20151513 foreign students (among them 738 were taught in English) were enrolled, in 2016 - 1719 foreign students (among them 1022 were taught in English), in 2017 - all 930 foreign students obtained programmes in English (Slipchuk, 2018). In 2018 - 2242 foreign students and in 20193160 foreign students were enrolled (Vlasenko, 2019).

These trends focus our research on studying current needs (country of origin, educational background, course preferences, satisfaction, ways of study funding) and perspectives (future career plans) of international medical students in Bogomolets National Medical University. We strongly believe that the results of one university, situated in the capital of the country, can reflect the general situation in Ukraine. Thus, the survey conducted in Bogomolets National Medical University in 2019 found the following:

1. Enrolment of international students by origin shows that they mainly come from Asia, Africa and former Soviet Union Republics. Top countries of origin of international students are Iran, Egypt and Morocco (See Fig. 3).

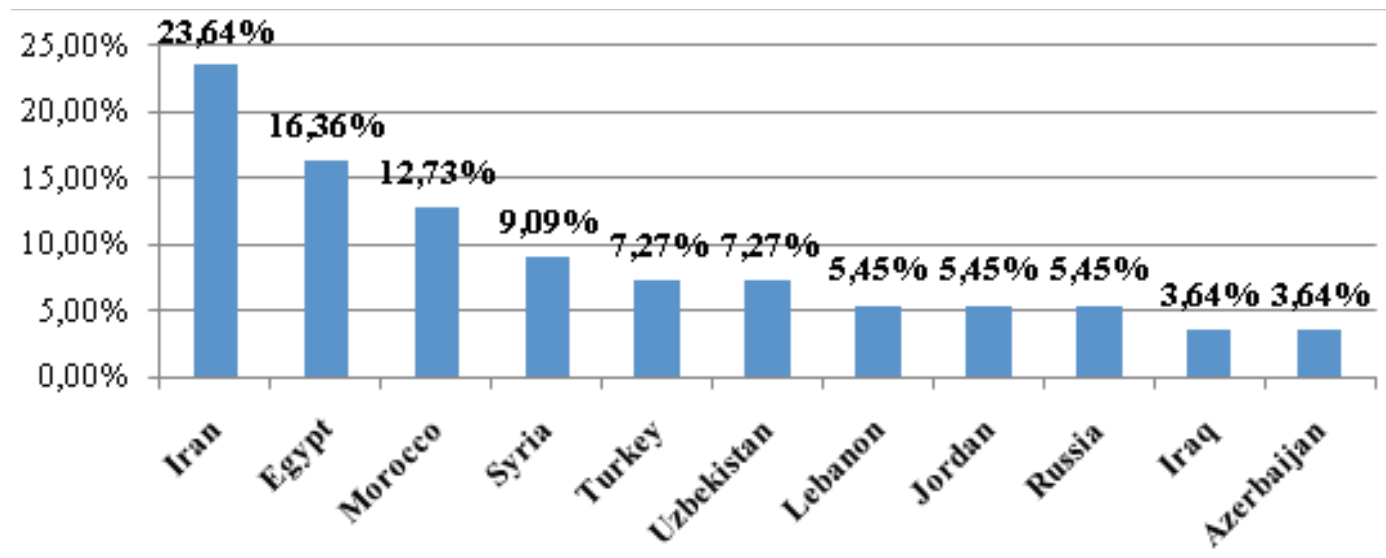

Figure 3. Enrolment of international students by origin in 2019

1. Education background of international medical students shows that they have completed secondary education - they can speak foreign language (predominantly English) and are good at Maths (58,62\%

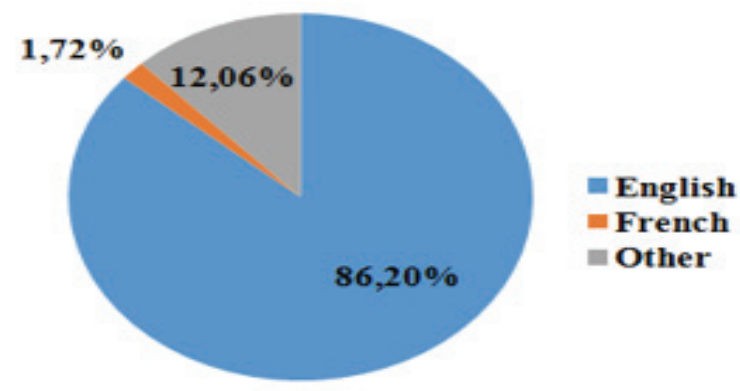

Figure 3. Speaking foreign language

2. The language of entrance interview was suggested in English and Ukrainian. English as a language for communication at the interview was chosen by those international medical students, who chose the course in English $-79,31 \%$ (46 respondents). Ukrainian for the interview was chosen by those international medical students, who chose the course in Ukrainian - 20,69\% (12 respondents). That shows that English-taught courses are becoming more demanded by foreigners and need to be developed in future in Bogomolets National Medical University.

3. Ukraine as a country of international medical students' destination for higher medical or chose it for entrance interview). Among other subjects that international medical students choose for the interview for the university are Biology $(51,72 \%)$ and Chemistry (41,38\%) (See Fig. 3-4).

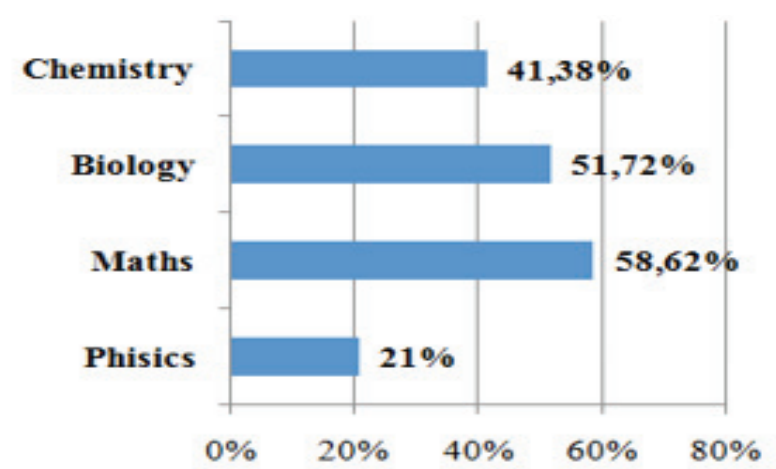

Figure 4. Interview subjects

pharmaceutical education. Among the reasons of international students' choice of Ukraine as a place for study are enjoy the country $(36,20 \%)$, high quality education and friends' advice (31,03\%), geographical location (25,86\%) (See Fig. 5). That indicates that while choosing the country for education international students rely predominantly on the experience of the previous international students' population who are likely to have learned or have visited Ukraine before. They were and are satisfied with high quality medical education. Geographical location of the country plays an important role either as it can be a good spot for further student or job mobility. 


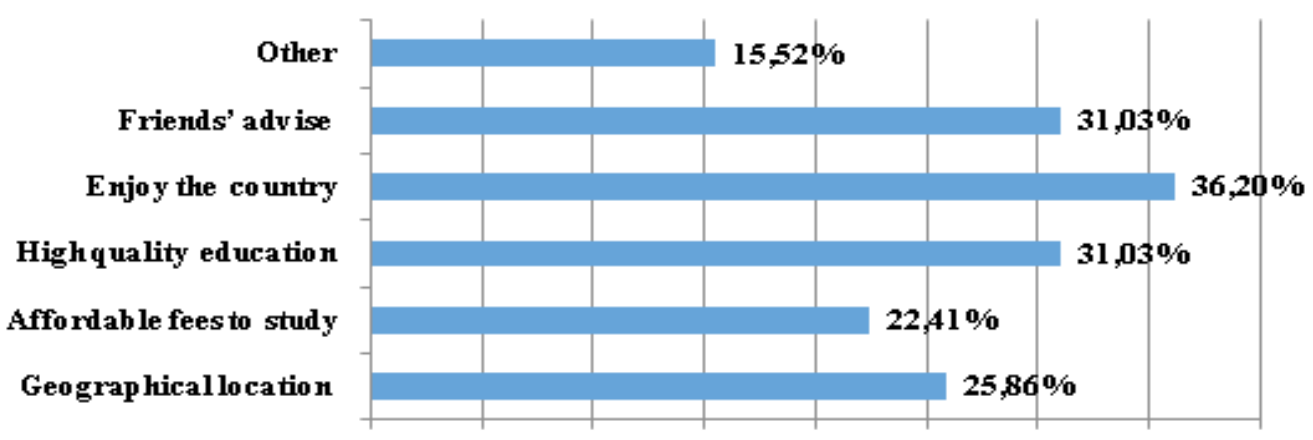

Figure 5. Reasons for higher education in Ukraine for international medical students

4. Bogomolets National Medical University as an institution of obtaining higher medical or pharmaceutical education by international students. Among the reasons of international students' choice of Bogomolets National Medical University as a place for study are the following: friends' advice (50\%), high quality education $(41,38 \%)$ and course information $(20,70 \%)$ (See Fig. 6). That indicates that while choosing the country for education international students also rely predominantly on the experience of the previous international students' population who are likely to have learned in Bogomolets National Medical University before. They were and are satisfied with high quality medical education at that university. Course information plays an important role as well in attracting new international customers of educational medical service.

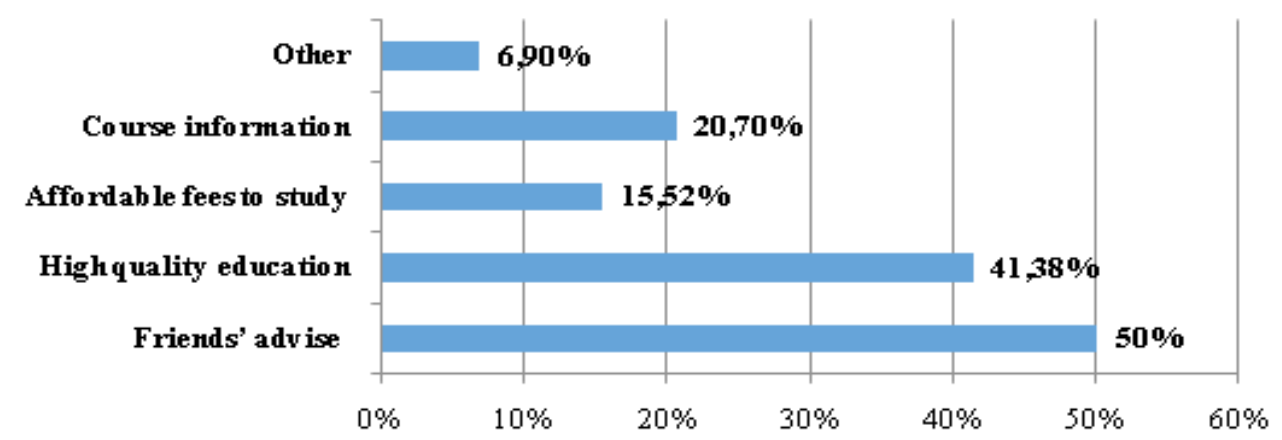

Figure 6. Reasons for higher education in Bogomolets National Medical University

5. The most demanded programme by international medical students at Bogomolets National Medical University in 2019 is «Dentistry». Among such provided programmes as «Medicine», «Pharmacy» and «Dentistry» - the last was chosen by majority of respondents $(82,76 \%)$ (See Fig.7).

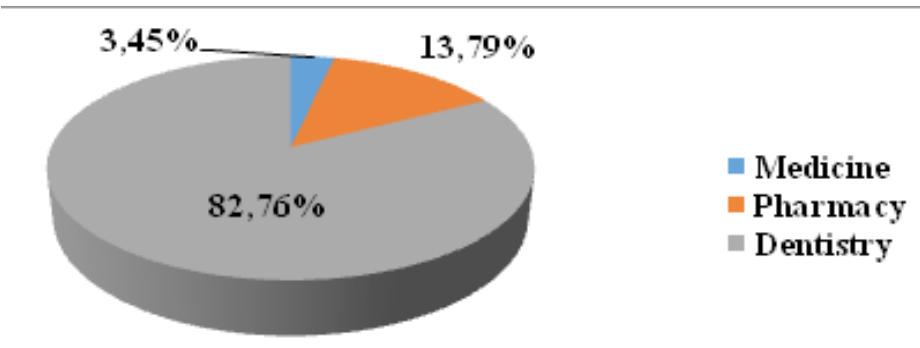

Figure 7. Demanded programmes by international medical students

6. The way to finance the study by international $\quad(87,72 \%)$. Such ways as student grants $(3,51 \%)$ and state medical students is predominantly parent's money funding (1,75\%) are less common (See Fig.8).

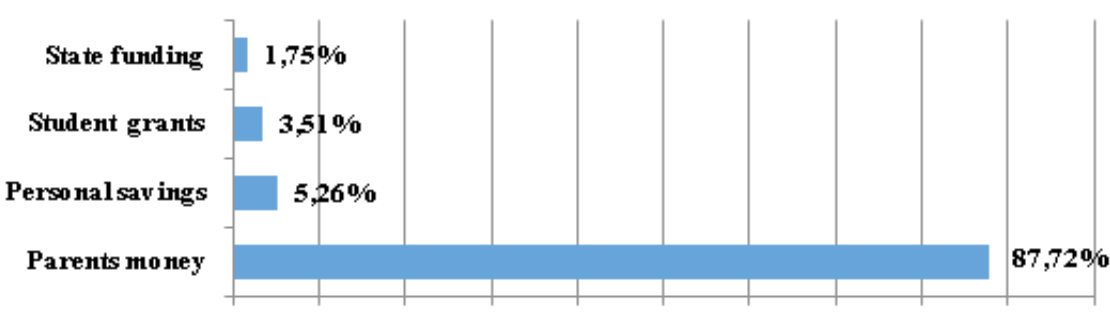

Figure 8. Ways to finance the study 
7. The future career plans of international medical students show that the majority of them are planning to come back home and be employed there $(43,86 \%)$, while $29,82 \%$ of respondents have other plans. It is important to note, that $15,79 \%$ of respondents consider Ukraine as their future place of employment. The EU as a future work destination attracts minority of respondents 10,53\% (See Fig.9).

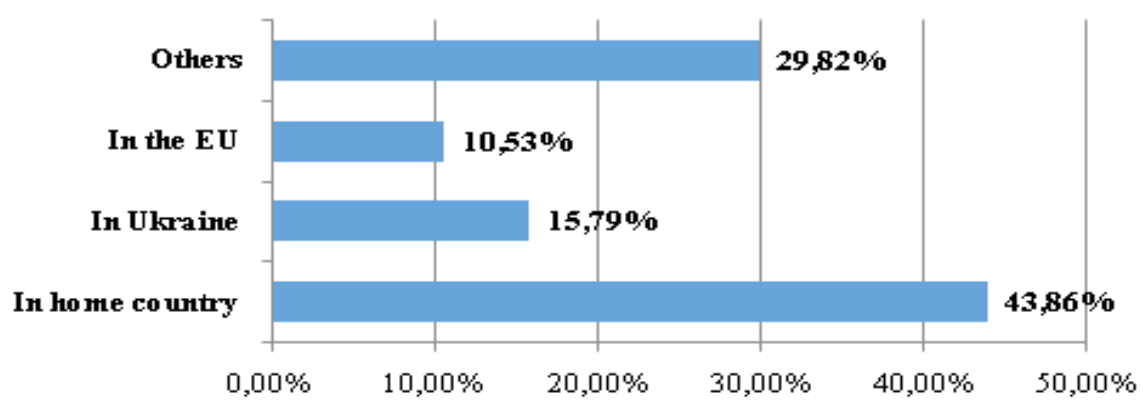

Figure 9. Career plans of international medical students

Discussion. This research aimed at analyzing current state of play of international medical student population in Ukraine. The study shows that increasing number of foreign students is one of the prospective directions of higher medical education modernization in Ukraine. The number of foreign students in medical universities of Ukraine has been constantly rising since 2006. Top 3 countries of origin of international students in Ukraine are India, Nigeria and Morocco. The Master programmes for international medical students are provided by 12 national medical universities, among which Kharkiv National Medical University is the leader in medical higher education services. Furthermore, since 2015, trends in increasing international students in Master and postgraduate programmes, taught in English, have been observed in Bogomolets National Medical University in Kiev. These trends allowed us to provide a survey to study country of origin, educational background, course preferences, satisfaction, ways of study funding and future career plans of international medical students in Bogomolets National Medical University.

According to the survey results we may conclude that in Bogomolets National Medical University top countries of origin of international medical students are Iran, Egypt and Morocco. Speaking English and knowing Maths and Chemistry make an evidence of completed secondary education at international medical students. $79,31 \%$ of international students choose courses taught in English. That makes provision of the same courses in Ukrainian for foreign students less demanded. Among the reasons of international students' choice of Ukraine as a place for study are their preference of the country, high quality education, friends' advice and geographical location. That indicates that while choosing the country for education international medical students rely predominantly on the experience of the previous international students' generation who are likely to have learnt or have visited Ukraine before. They were and are satisfied with high quality education at national medical universities. Among the reasons of international students' choice of Bogomolets National Medical University as a place for study are friends' advice, high quality education and course information. That evidences that while choosing the university, international students also rely predominantly on the experience of the previous international students' generation who are likely to have learnt in Bogomolets National Medical University before. The most demanded programme by international students at Bogomolets National Medical University in 2019 is «Dentistry». The way to finance the study by international students is predominantly parent's money. Such ways as student grants and state funding are less typical. The future career plans of international medical students show that the majority of them are planning to come back home and be employed there. It is important to note, that $15,79 \%$ of respondents consider Ukraine as their future place of employment. The EU as a future work destination is less popular.

The main finding of the study is that international medical students consider Ukraine not only as high quality medical education provider but as perspective country for postgraduate employment.

Limitations. This study has certain limitations. The first limitation is the low response rate. From expected 100 students only 60 students sent their responses. The rest ones were less likely to participate in the survey due to unknown reasons. Another weakness is one university as a place of conducting the survey. However, the research results allow us to hypothesise that the current needs and perspectives of international medical students at one medical university are likely to be typical for other national medical universities and for Ukraine in whole. This hypothesis will be proved or disapproved in the future researches.

Conclusion. The findings of the study show that Ukraine is not only one of the biggest suppliers of international students to the European Union in EHEA, but it is also a host country for international students primarily from Asia and Africa. Ukraine as a study destination attracts international medical students, first, by high quality education and then, by affordable tuition fees. English-taught programmes are becoming more demanded by international medical students. 
Some of them even consider Ukraine as a place of future employment. In conclusion we should say, that due to increasing international students' population in national medical universities their current needs and perspectives demand regular monitoring and special researches from universities and government. We believe that these measures will make benefits in international university strategy and national educational policy coordination.

\section{References}

Attracting and retaining international students in the EU Common Template for EMN Study (2019). https:// ec.europa.eu/home-affairs/sites/homeaffairs/files/08a_estonia_attracting_retaining_students_final_en.pdf

Breen, K., Birrell, B. (2020). Selling medical education to international students: time for review. Internal Medicine Journal, 50 (5), 635-637. 10.1111/imj.14821

Busby, E. (2018). Number of EU applicants to UK medical schools falls to lowest point in decade, figures show. Independent. Thursday, 25 October. https://www.independent.co.uk/news/education/education-news/ students-university-medicine-health-brexit-latest-undergraduate-ucas-admissions-a8601121.html

Byrne, E., et al. (2019). 'A melting pot of cultures' - challenges in social adaptation and interactions amongst international medical students. BMC Medical Education, 19 (1). 10.1186/s12909-019-1514-1

European Commission/EACEA/Eurydice (2018). The European Higher Education Area in 2018: Bologna Process Implementation Report. Publications Office of the European Union. https://eacea.ec.europa.eu/nationalpolicies/eurydice/sites/eurydice/files/bologna_internet_0.pdf

Expansion of Undergraduate Medical Education. A consultation on how to maximise the benefits from the increases in medical student numbers. (2017). https://assets.publishing.service.gov.uk/government/uploads/system/ uploads/attachment_data/file/600835/Medical_expansion_rev_A.pdf

Herrmann-Werner, A. et al. (2018). Reducing Stress and Promoting Social Integration of International Medical Students through a Tandem Program: Results of a Prospective-Program Evaluation. International Journal of Environmental Research and Public Health, 15 (9). 10.3390/ijerph15091959

Huhn, D., et al. (2018). A Comparison of Stress Perception in International and Local First Semester Medical Students Using Psychometric, Psychophysiological, and Humoral Methods. International Journal of Environmental Research and Public Health, 15 (12). 10.3390/ijerph15122820

Iorga, M., et al. (2020). Factors Associated with Acculturative Stress among International Medical Students. BioMed Research International. 10.1155/2020/2564725

Kelo, M., Rogers, T., \& Rumbley, L. E. (2010). International Student Support in European Higher Education. Needs, Solutions, and Challenges. https://aca-secretariat.be/post_other_pub/international-student-supportin-european-higher-education-needs-solutions-and-challenges/

Li, W., Sun, H. (2019). Migration intentions of Asian and African medical students educated in China: a crosssectional study. Human Resources for Health, 17 (1). 10.1186/s12960-019-0431-z

Medical Research Education in Europe. (2012). Science Policy Briefing. September, 20. http://archives.esf.org/ fileadmin/Public_documents/Publications/spb46_MedResEurope.pdf

Migration Advisory Committee Call for Evidence: the impact of international students in the UK (2017). https:// www.bma.org.uk/-/media/files/pdfs/collective\%20voice/ influence/uk\%20governments/consultationresponse-mac-students-commission-august-2017.pdf?la=en

Potočnjak, I. et al. (2018). The attitudes of international medical students toward educational methods and styles applied in a 6-year longitudinal course in fundamentals of medical skills in Croatia. Croatian Medical Journal, 59 (5), 267-273. 10.3325/cmj.2018.59.267

Romanenko, M. (2017). 64,000 foreigners attend universities in Ukraine. Kyiv Post. Ukraine’s Global Voice. Feb. 9. https://www.kyivpost.com /ukraine-politics/64000-foreigners-attend-universities-ukraine.html

Sysoieva, S., Mospan, N. (2015). New Law of Higher Education in Ukraine: innovations and risks. Didactica Slovenica, 30 (3-4), 166-174. http://www.pedagoska-obzorja.si/revija/Vsebine/PDF/DSPO_2015_30_03.pdf

Amosova, K. M. (2017). Pro stan ukrayinskoyi vishoyi medichnoyi osviti, vikliki chasu i napryami rozvitku: dosvid NMU imeni O. O. Bogomolcya i propoziciyi do derzhavnoyi politiki [Ukrainian higher medical education status, challenges and development: experience of Bogomolets National Medical University and political proposals]. https://nmuofficial.com/wp-content/uploads/2017/02/PREZENTACIA.pdf

Vlasenko, O. M. (2019). Pidsumki navchalno-metodichnoyi roboti universitetu za 2018/2019 n. r. i prioritetni zavdannya na 2019/2020 n.r. [Results of educational and methodological work of Bogomolets National Medical University for 2018/2019 and priorities for 2019/2020]. https://rive.google.com/file/d/134fs0VKr1zfPtcEO mwEOt4L9GeuL4UDm/view

Zakon Ukrainy «Pro vyshchu osvitu» [Law of Ukraine On Higher Education] (2014). https://zakon.rada.gov.ua/ laws/show/1556-18

Slipchuk, V. L. (2019). Formuvannya komunikativnih kompetentnostej inozemnih studentiv u zakladah vishoyi medichnoyi osviti Ukrayini [Development of Communicative Competences of Foreign Students in Higher 
Medical Education Institutes in Ukraine]. Continuing Professional Education: Theory and Practice, 2, 52-57. http://dx.doi.org/10.28925/1609-8595.2019.2.5257.

Fisun, Y. I. (2015). Organization of foreign students training in the current academic year. Report.

\section{Література}

Attracting and retaining international students in the EU Common Template for EMN Study. 2019. URL: https:// ec.europa.eu/home-affairs/sites/homeaffairs/files/08a_estonia_attracting_retaining_students_final_en.pdf (дата звернення: 10.09.2020)

Breen K., Birrell B. Selling medical education to international students: time for review. Internal Medicine Journal. 2020. № 50 (5). P. 635-637. DOI: 10.1111/imj.14821

Busby E. Number of EU applicants to UK medical schools falls to lowest point in decade, figures show. Independent. 2018. Thursday, 25 October. URL: https://www.independent.co.uk/news/education/education-news/studentsuniversity-medicine-health-brexit-latest-undergraduate-ucas-admissions-a8601121.html (дата звернення: 10.09.2020)

Byrne E. et al. 'A melting pot of cultures' - challenges in social adaptation and interactions amongst international medical students. BMC Medical Education. 2019. № 19 (1). DOI: 10.1186/s12909-019-1514-1

European Commission/EACEA/Eurydice. The European Higher Education Area in 2018: Bologna Process Implementation Report. Luxembourg: Publications Office of the European Union, 2018. URL: https://eacea. ec.europa.eu/national-policies/eurydice/sites/eurydice/files/bologna_internet_0.pdf (дата звернення: 12.09.2020)

Expansion of Undergraduate Medical Education. A consultation on how to maximise the benefits from the increases in medical student numbers. 2017. URL: https://assets.publishing.service.gov.uk/government/uploads/system/ uploads/attachment_data/file/600835/Medical_expansion_rev_A.pdf (дата звернення: 10.09.2020)

Herrmann-Werner A. et al. Reducing Stress and Promoting Social Integration of International Medical Students through a Tandem Program: Results of a Prospective-Program Evaluation. International Journal of Environmental Research and Public Health. 2018. № 15 (9). DOI: 10.3390/ijerph15091959

Huhn D. et al. A Comparison of Stress Perception in International and Local First Semester Medical Students Using Psychometric, Psychophysiological, and Humoral Methods. International Journal of Environmental Research and Public Health. 2018. № 15 (12). DOI: 10.3390/ijerph15122820

Iorga M., et al. Factors Associated with Acculturative Stress among International Medical Students. BioMed Research International. 2020. DOI: 10.1155/2020/2564725

Kelo M., Rogers T., \& Rumbley L. E. International Student Support in European Higher Education. Needs, Solutions, and Challenges. 2010. URL: https://aca-secretariat.be/post_other_pub/international-student-support-ineuropean-higher-education-needs-solutions-and-challenges/ (дата звернення: 01.09.2020)

Li W., Sun H. Migration intentions of Asian and African medical students educated in China: a cross-sectional study. Human Resources for Health. 2019. № 17 (1). DOI: 10.1186/s12960-019-0431-z

Medical Research Education in Europe. Science Policy Briefing. 2012. September. 20. URL: http://archives.esf. org/fileadmin/Public_documents/Publications/spb46__MedResEurope.pdf (дата звернення: 01.09.2020)

Migration Advisory Committee Call for Evidence: the impact of international students in the UK. 2017. URL: https://www.bma.org.uk/-/media/files/pdfs/collective\%20voice/ influence/uk\%20governments/consultationresponse-mac-students-commission-august-2017.pdf?la=en (дата звернення: 10.09.2020)

Potočnjak I. et al. The attitudes of international medical students toward educational methods and styles applied in a 6-year longitudinal course in fundamentals of medical skills in Croatia. Croatian Medical Journal. 2018. № 59 (5). P. 267-273. DOI: 10.3325/cmj.2018.59.267

Romanenko M. 64,000 foreigners attend universities in Ukraine. Kyiv Post. Ukraine's Global Voice. 2017. Feb. 9. URL: https://www.kyivpost.com /ukraine-politics/64000-foreigners-attend-universities-ukraine.html (дата звернення: 07.09.2020)

Sysoieva S., Mospan N. New Law of Higher Education in Ukraine: innovations and risks. Didactica Slovenica. 2015. № 30 (3-4). P. 166-174. URL: http://www.pedagoska-obzorja.si/revija/Vsebine/PDF/DSPO_2015_30_03. pdf (дата звернення: 01.09.2020)

Амосова К. Про стан української вищої медичної освіти, виклики часу і напрями розвитку: досвід НМУ імені О. О. Богомольця і пропозиції до державної політики. 2017. URL: https://nmuofficial.com/wpcontent/uploads/2017/02/PREZENTACIA.pdf (дата звернення: 14.09.2020)

Власенко О. М. Підсумки навчально-методичної роботи університету за 2018/2019 н. р. і пріоритетні завдання на 2019/2020 н. p. 2019. URL: https://drive.google.com/file/d/134fs0VKr1zfPtcEOmwEOt4L9G euL4UDm/view

Закон України «Про вищу освіту». 2014. URL: https://zakon.rada.gov.ua/laws/show/1556-18 (дата звернення: $01.09 .2020)$ 
Сліпчук В. Формування комунікативних компетентностей іноземних студентів у закладах вищої медичної освіти України. Неперервна професійна освіта: теорія і практика. 2019. № 2. C. 52-57. DOI: http://dx.doi.org/10.28925/1609-8595.2019.2.5257.

Fisun, Y. I. (2015). Organization of foreign students training in the current academic year. Report.

\title{
НАВЧАННЯ ІНОЗЕМНИХ СТУДЕНТІВ У ЗАКЛАДАХ ВИЩОЇ МЕДИЧНОЇ ОСВІТИ УКРАЇНИ: СТАН І ПЕРСПЕКТИВИ
}

\author{
Мосьпан Наталя, доктор педагогічних наук, доцент, \\ професор кафедри англійської філології та перекладу, \\ Інститут філології, Київський університет імені Бориса Грінченка, \\ вул. Тимошенка, 13-Б,04212 Київ, Україна, Monavik@ukr.net \\ Сліпчук Валентина, доктор педагогічних наук, доцент, \\ професор кафедри медичної та загальної хімії, \\ Національний медичний університет імені О. О. Богомольця, \\ бул. Тараса Шевченка, 13, 01601 Київ, Україна, slipchukvl@gmail.com
}

у статті дослідується сучасний стан міжнародного студентського населення в Україні, чия кількість у національних медичних університетах постійно зростає з 2006 року. Україна є країною для отримання вищої медичної або фармачевтичної освіти іноземними студентами. Україна є не тільки одним з найбільших постачальників іноземних студентів до Європейсъкому просторі вищої освіти, але вона також є країною, що приймає іноземних студентів, переважно з Азії та Африки. Опитування, спрямоване на вивчення сучасних потреб та перспектив навчання міжнародних студентів-медиків, було проведено в Національному медичному університеті імені О. О. Богомольия у 2019 році. Вибірку складали 60 студентів-медиків першого курсу, вибраних випадковим чином. Це дозволило студентам надати відгуки про свою країну походження, освіту, уподобання, задоволеність якістю освітніх послуг у приймаючій країні, шляхи фінансування навчання та майбутні кар'єрні плани. Серед причин, за якими іноземні студенти обирають Україну як місце для навчання - переваги країни, високоякісна освіта, поради друзів та географічне розташування. Результати дослідження показують, що іноземні студенти-медики розглядають Україну не лише як країну, що надає високоякісну медичну освіту, а й як перспективну країну для післядипломної роботи. Результати дослідження дозволяють припустити, що сучасні потреби та перспективи міжнародних студентів-медиків одного медичного університету, ймовірно, будуть типовими для інших національних медичних університетів та для України в цілому. Зроблено висновок, що збільшення кількості іноземних студентів вимагає регулярного моніторингу та спеціальних досліджень з боку університетів та уряду. Ці заходи посприяють виробленню кращої стратегї надання якісних освітніх послуг на університетському та державному рівнях з урахуванням як потреб іноземних споживачів, так і майбутніх глобальних змін.

Ключові слова: вища медична освіта; іноземні студенти-медики; медичні університети; потреби та перспективи студентів; прачевлаштування.

\section{ОБУЧЕНИЕ ИНОСТРАННЫХ СТУДЕНТОВ В ВЫСШИХ МЕДИЦИНСКИХ УЧЕБНЫХ ЗАВЕДЕНИЯХ УКРАИНЫ: СОСТОЯНИЕ И ПЕРСПЕКТИВЫ}

\author{
Мосьпан Наталья, доктор педагогических наук, доцент, \\ профессор кафедры английской филологии и перевода, \\ Институт филологии, Киевский университет имени Бориса Гринченко, \\ ул. Тимошенко, 13-Б, 04212 Киев, Украина, Monavik@ukr.net \\ Слипчук Валентина, доктор педагогических наук, доцент, \\ профессор кафедры медицинской и общей химии, \\ Национальный медицинский университет имени А. А. Богомольца, \\ бул. Тараса Шевченко, 13, 01601 Киев, Украина, slipchukvl@gmail.com
}

В статье исследуется современное состояние обучения иностранных медицинских студентов в Украине. Их количество в национальных медицинских университетах постоянно растет с 2006 года. 
Украина становится страной для получения высшего медищинского или фармацевтического образования иностранными студентами-медиками. Опрос, направленный на изучение современных потребностей и перспектив иностранных студентов-медиков, был проведен в Национальном медицинском университете имени А. А. Богомольца в 2019 году. Выборка состояла из 60 иностранных студентовпервокурсников, избранных случайным образом. Это позволило студентам предоставить отзывы о стране происхождения, образовании, предпочтениях, удовлетворенности качеством образовательных услуг в принимающей стране, способах финансирования обучения и будущих карьерных планах. Результаты исследования показывают, что иностранные студенты-медики рассматривают Украину не только как поставщика высококачественного медищинского образования, но и как перспективную страну для последипломного трудоустройства. Сделан вывод, что растущее количество иностранных студентов требует регулярного мониторинга и специальных исследований со стороны университетов и правительства для выработки стратегии предоставления качественных образовательных услуг с учетом как потребностей иностранных потребителей, так и будущих глобальных изменений.

Ключевые слова: высшее медицинское образование; иностранные студенты-медики; медицинские университеты; потребности и перспективы студентов; трудоустройство.

Article was:

Received 14.09.2020

Accepted 24.09.2020 